\title{
走査電子顕微鏡によるジャコウネズミ (Suncus
}

\section{murinus) の舌背粘膜の微細構造}

\author{
岩 崎信一坂田公一森秀樹 \\ 上野瑞生子小林寛
}

日本歯科大学新潟歯学部口腔解剖学教室第一講座（主任 : 小林 寛教授）

「受付 : 昭和 58 年 3 月 7 日〕

\section{Ultrastructure of the lingual dorsal surface in Suncus murinus (Linne)}

\author{
Shin-ichi Iwasaki, Koichi Sakata, Hideki Mori, \\ Minako Ueno and Kan Kobayashi \\ Department of Oral Anatomy, Nippon Dental University, \\ 1-8, Hamaura-cho, Niigata 951 \\ (Chief: Prof. Kan Kobayashi)
}

[Accepted for publication: March 7, 1983]

Key words : lingual papillae / microridge/SEM / Suncus murinus

\begin{abstract}
The lingual dorsal surface of the musk shrew, Suncus murinus, was examined by scanning electron microscopy after removal of the extracellular material by acid hydrolysis. The tongue of this species is long and slender with a narrowly protruding tip. Filiform papillae were distributed over the entire dorsal surface of the tongue excepting the lingual radix zone. The upper part of the conical filiform papillae was branched into several twigs while the middle anterior revealed a round slope. A relatively small number of fungiform papillae were seen scattered among the filiform papillae. The dome-shaped fungiform papillae were shorter and wider than the filiform papillae.

Microridges were widely distributed on the epithelial cell surface between the filiform and fungiform papillae. The free surface of the filiform. fungiform and circumvallate papillae, however, were devoid of distinct microridges. The results were discussed in relation to the possible role of microridges in the keratinization of the lingual epithelial cells.
\end{abstract}

\section{緒言}

哺乳類の舌背粘膜表面には, 系状乳頭が密生し, 咠状乳頭, 葉状乳頭, 有郭乳頭といった形態の異 なる乳頭も存在する。走査電顕による舌乳頭の形 態学的な研究は静歯目のラット，マウス，八ムス ターや翼手目のコウモリなどでかなり報告されて いるが1-6)，食虫目に関しては極めて少ない。

そこで今回我々は，食虫目トガリネズミ科に属 するジャコウネズミにおいて，舌背の系状乳頭，

新潟市泜浦町 1-8（产 951）
茸状乳頭および有郭乳頭を 走査電子顕微鏡によっ て観察するとともに，舌乳頭を含む舌背の各部の 粘膜上皮表面の微細構造を 同じく走査電子顕微鏡 によって観察を行った。口腔粘膜上皮の表面に は，広範囲に微小堤が存在していることが知られ ており ${ }^{7-12)}$ ，高木ら ${ }^{13)}$ はヒトの舌背においても広 く微小堤が存在することを報告している。しかし ヒト以外の哺乳類では, 舌尖, 舌体部の舌背に微 小堤を確認している報告は少ないように思われ る。以上の事から, 哺乳類の舌尖, 舌体部の舌背 表面に，微小堤が存在するか否か，および舌背表 
面の微細構造に 部位的な差異があるかどうかを知 ることは興味ある課題である。

通常，口腔内には多量の粘性物質が存在してお り，系状乳頭など著しく起伏に富んだ前舌におい ては，舌粘膜上皮表面の微細構造の観察には，表 面に堆積している粘性物質を除去する必要があ る。上原 ${ }^{14)}$ は， 腺組織腺房表面などの走查電子顕 微鏡観察に際して 高濃度 $\mathrm{HCl}$ で処理することに より，細胞間結合組織を容易に除去し得ることを 報告している。今回の観察においては，上原の方 法が舌背表面の粘性付着物の 除去にも適用できる のではなかろうかという想定のもとに，高濃度の $\mathrm{HCl}$ で舌を処理してから走査電子顕微鏡試料の作 製を試みた。

\section{材料および方法}

材料としては，生後 $1 \sim 3$ か月（体重30～50g） の雌雄ジャコウネズミ(Suncus murinus) 各 9 匹 計18匹を用いた。

動物はエーテル麻酔下で パラホルムアルデヒド とグルタールアルデヒドを含む Karnovsky 液 ${ }^{15)}$ の全身灌流固定後，舌を摘出し，同液でさらに浸 漬固定を行ってから $0.1 \mathrm{M}$ カコジレート緩衝液 で洗浄した後，表面を被覆している粘液など堆積 物の除去を試みた。すなわち, $1 \% \mathrm{OsO}_{4}{ }^{16)}$ で $37^{\circ} \mathrm{C} ， 2$ 時間後固定を行ってから水洗し， $8 \mathrm{~N}$ 塩 酸で $60^{\circ} \mathrm{C} ， 30$ 分間処理した。この後は，通法に従 って脱水, 臨界点乾燥後, 金蒸着を施して日立走 査電子顕微鏡 (S-500型) で観察した。

また，対照として上記の $\mathrm{OsO}_{4}$ と $\mathrm{HCl}$ の処理 を施さずに，通常の脱水，臨界点乾燥を行い金蒸 着を施した試料を作製し，前者と比較しながら観 察を行った。

\section{結果}

ジャコウネズミの舌は，横径に比して前後径が 長く，先端部は細長く突起する(Fig. 1，2)。

走査電子顕微鏡により舌背部を拡大して観察す ると，系状乳頭が舌尖部，舌体部の舌背全面を被 って密生し, 全体としては先端部を後方に向けて 傾斜するが，部位によりその方向は多少異なる。 即ち舌の正中線を境にして左右の系状乳頭はほぼ
対称的な配列を示し，前舌の前半部では舌縁部の ものはその先端が後外側方に傾斜するが, 正中線 に近つくにつれて後内側方に傾斜する。しかし， 前舌の後半部においてはそのような傾向はあまり 明瞭ではない。

大部分の糸状乳頭は径がほぼ $40 \mu \mathrm{m}$ で乳頭中程 に，後上方から前下方に傾斜した円形の斜面をも ち, 数個に分かれた乳頭の小突起が 舌根側から半 円形にこの斜面をとり囲んで配列している（Fig. 3)。このような特徵的な 基本形態には著しい部 位的な相違はみられないが，系状乳頭先端部の小 突起は舌尖に近づくほど 乳頭の先端に近いところ で 2 数個に分岐し，後方にゆくに従って小突起 の分岐点は下方にあって $2 \sim 3$ の小突起が 極めて 長くなる傾向を示す(Fig．4，5)。茸状乳頭は系状 乳頭の間に散在しており，形態は采状乳頭よりも 径が大きく(約 $60 \mu \mathrm{m})$, 丈は低く, 円丘状を呈する (Fig. 3，6)。舌尖から後外側へ彎曲しながら伸 びる両舌縁に沿って10個程度の茸状乳頭が一列に 密に並ぶのが観察された (Fig. 2)。有郭乳頭は前 舌の後端に位置し，咠状乳頭よりはかなり大きく (径約 $450 \mu \mathrm{m}$ )，上面の中央にある 乳頭部は 平担 な円丘状を呈し，深い溝に囲まれている。その溝 の外側はドーナツ状の外郭によって囲まれており 全体として円形あるいは長棈円形を呈している。 個体により異なるが，数個存在する (Fig. 7)。分 界溝の外側前方に葉状乳頭に相当すると思われる 数条の縦に走るひだが観察された。

Fig. 8 は，通常の方法に従って固定した舌をそ のまま脱水，臨界点乾燥を行ってから，金蒸着 を施して走査電子顕微鏡の強拡大で 観察した像で ある。采状乳頭間に狭まれた舌背粘膜の表面であ るが，ここには粘性の付着物が堆積している。こ の堆積物のさけ目から，微小堤をもった粘膜上皮 の表面がのぞき見られる(Fig. 8，EP)。Fig. 9 は, 固定後 $1 \% \mathrm{OsO}_{4}$ と $8 \mathrm{~N} \mathrm{HCl}$ で処理した舌 を脱水，臨界点乾燥を行い，金蒸着を施した試料 の采状乳頭間にひろがる 舌背部の粘膜表面の像で ある。表面の堆積物はきれいに除去されており， 細長いひだが，密に網目をつくって広がった微小 堤が粘膜上皮の表面全体に観察される。このよう な微小堤を有する粘膜上皮は，その他にも系状乳 
頭の円形斜面（Fig. 10）や舌根部の粘膜上皮の表 面にも認められている。しかし，系状乳頭の下 $1 / 3$ くらいから先端にかけてはこのような微小堤の存 在は不明瞭で, 全体に散らばった小孔を有する比 較的平滑な表面をなす(Fig. 11)。ここでは, 乳頭 の先端部をおおう最上層の細胞の境界部がやや肥 厚し，彎曲したすじとして観察される (Fig. 11, 矢印)。また, 茸状乳頭 (Fig. 12) や, 有郭乳頭 の表面でも，この微小堤構造は明瞭ではなく, 多 数の小孔をもった扁平な細胞が広がる。

一方, 舌根部の粘膜上皮表面については， $1 \%$ $\mathrm{OsO}_{4}$ と $8 \mathrm{~N} \mathrm{HCl}$ の処理を行わなかった試料に ついても微小堤は明瞭に認められ(Fig. 13), この 部分への粘性付着物の堆積は舌尖部, 舌体部の舌 背表面に比べて 比較的少ないものと思われる。

Fig. 14は, 舌背断端を走查電子顕微鏡により観 察したもので, 最表層から，十層程度下層にいた る細胞の層が斜上方から眺められ, 全ての層の細 胞の表面に密に配列した網状或るいは平行条をな した微小堤が観察される(Fig. 14, 15)。

\section{考察}

舌の形や舌粘膜, 特に舌乳頭の形態が食物の捸 取, 咀嚼, 嚥下などといった舌機能と密接な関係 のあることは充分に予想されるところであるが， 舌の微細な形態とその機能との関連性を系統的に 考察するにはまだ十分な研究がなされていない。 これまで舌乳頭に関する走査電顕による研究は,

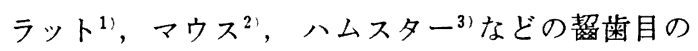
ものや，翼手目に属するコウモリ ${ }^{4-6)}$ の報告があ る。藤田ら ${ }^{13}$ は八ムスターの舌背粘膜上皮の走查 電顕による観察を行い, 系状乳頭に関してはそ の形態, 大きさ, 配列の方向, 表面の微細構造の 差異から, 舌前方 $2 / 3$ 部の系状乳頭, 舌隆起部の 糸状乳頭, 後 $1 / 3$ 部の糸状乳頭の 3 種類に分類し て報告した。確かに部位による差は認められるが， 基本的にはラット，マウスの糸状乳頭はほぼ円錐 形を呈し，その先端は，やや後方に傾斜する ${ }^{1-2)}$ 。 これに対しハムスターでば" 手状乳頭はほぼ円錐 形で, 全体として後方に傾斜するが, 両側縁部が 前内方にまくれ込んで前面に凹窩を形成し，樋状 あるいは移植鏝状を呈する。コウモリの糸状乳頭
は針状の突起を多数有し，稲苗様の集塊を形成し たり，小麦の穂様を呈するものなどが観察されて (る ${ }^{4-6)}$ 。

今回のジャコウネズミでは 釆状乳頭は全体とし て円錐形を基本とし，後方に傾斜するが，その前 面のほぼ中央部に後上方から 前下方に向かって傾 斜する円形の斜面をもち，その後半部は数個に分 岐した小系状乳頭突起によってとり囲まれてい る。このようにジャコウネズミの采状乳頭の形態 はこれまでに観察された斐歯目のラット, マウス， 八ムスターや翼手目のコウモリの糸状乳頭などと む異なった特徴ある像を呈し, 種特異性のあるこ とを示しているが，これらの構造と食生活との関 連性などについては 今後の研究にまたねばならな い。

Hume and Potten ${ }^{2}$ は光顕および 走查電顕によ りマウスの系状乳頭は 系状乳頭前面部粘膜上皮細 胞列と系状乳頭後面部粘膜上皮細胞列とを区別 し，少なくとも 4 種類の細胞列より構成されるこ

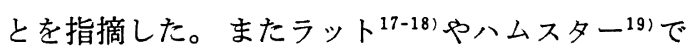
は光顕的に糸状乳頭前面部粘膜上皮, 系状乳頭後 面部粘膜上皮, 糸状乳頭間粘膜上皮はそれぞれ異 なる角化様式の認められることが報告された。更 に藤田ら ${ }^{3)}$ は光顕と走查電顕による研究からハム スターの采状乳頭が 次の 4 種類の細胞列から構成 されることを主張した。即ち前面部粘膜上皮細胞 列, 後面部粘膜上皮細胞列, 後面基部粘膜上皮細 胞列, 側面部粘膜上皮細胞列の 4 種類である。ジ ヤコウネズミにおける采状乳頭は, 走査電顕的に 極めて特徴のある構造を 示すことからこれらの各 部の組織学的な研究とあわせて今後, より詳細な 糹状乳頭の細胞構成を検討する必要がある。

走查型電子顕微鏡観察により上皮細胞の表面に 微小堤 (Microridges) が存在するという報告は多 数ある。また口腔粘膜上皮の表面にも微小堤が 存在するが、これらは動物種により，また部位 によってもその形態を異にする事が知られてい $3^{7-13,20)}$ 。哺乳類の舌根部の舌背粘膜上皮細胞の 表面に微小堤が存在することはすでに報告がなさ れており ${ }^{12)}$ ，今回の観察においても舌根部の舌背 表面では特に表面の付着物の除去操作を行わなく ても容易に微小堤の存在は確認された。その理 
由として微小堤の起伏が大きいこと，および舌尖 部, 舌体部に比べて舌根部の舌背表面には乳頭が 存在しないために付着物が少ないことによると考 えられる。これに対し前舌の舌背における微小堤 の有無に関してはヒト胎児において観察されてい るが13)，他の動物においてはまだ報告がないよう である。今回の観察で, 試料作製時の付着物の除 去処理を施さない場合には陥凹部にある付着物の 堆積のために微小堤の存在を 確認することは困難 であったが， $\mathrm{OsO}_{4}$ と高濃度 $\mathrm{HCl}$ 処理を施し表 面の付着物を除去した場合には系状乳頭基部をは じめ， 系状乳頭間の上皮細胞の表面に微小堤の存 在することが確認された。したがって動物の口腔 粘膜上皮表面は 通常多量の粘性の付着物でおおわ れており，前舌舌背のように多数の系状乳頭など により特に凹凸の著しいところの宿凹部には堆積 物が多いため，これらの充分な確認ができなかっ たものと考えられる。

ジャコウネズミの舌背の微小堤は 釆状乳頭間の 上皮細胞表面や 糸状乳頭の 基部には見出される が，系状乳頭の先端部や茸状乳頭，有郭乳頭の頭 部には認められない。高木ら ${ }^{131}$ はヒトの舌で微小 堤の発生過程を走查電顕で調へ， 発生初期の微小 堤は微絨毛様小突起として現われ，それらが数珠 状に融合して直線型となり，さらに部分的に癒合 して分岐型となり，ついに網目状となると報告し ている。これらの微小堤の 形態は上皮細胞の角 化の程度との関連性に㧍いてもとらえられてお

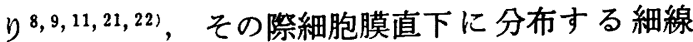
維の動態との関連性を強調する研究者もいる ${ }^{6 j}$ 。

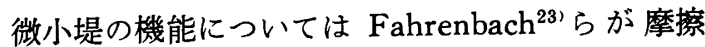
に対する上皮の適応形態であるとし，また Sperry ら ${ }^{24)}$ は上皮細胞表面での粘液の保持やその拡散に 都合のよい構造であると述べている。また外部か ら加わる種々の力に対応して 微小堤の構造が変化 することも考えられるが，いずれも推測の域を出 ない。今後の研究が待たれるところである。

\section{結論}

ジャコウネズミの舌背粘膜表面を 走査型電子顕 微鏡で観察し，次のような結果を得た。

1. 系状乳頭は後方に傾斜するが，上方からみ ると舌縁に近いもの程先端は後外方に，正中線に 近いものでは先端は後内方に向かって傾斜する。

2. 糸状乳頭は円錐形で，その中程に後上方か ら前下方に向から円形の傾斜面があり，数個に分 かれた突起がこれを後方から 半円形にとり囲む。

3. カルノフスキー液で固定後, $1 \% \mathrm{OsO}_{4}$ と $8 \mathrm{~N} \mathrm{HCl}$ 処理を施した舌試料の走査電子顕微鏡 像で系状乳頭基部，糸状乳頭間部および舌根部の 舌背を構成する粘膜上皮細胞の 表面に密な配列を 示す微小堤を観察することができた。

4. 上記の処理を施した舌試料においても，釆 状乳頭の上半部や咠状乳頭, 有郭乳頭の頭部には, 微小堤は認められず比較的平滑な面に小孔が散在 性に観察された。

抄録: 食虫目トガリネズミ科に属するジャコウネズミの舌を固定後, 高濃度塩酸処理を施して, 走查電顕 用試料を作製し観察した。舌の全体像は横径に比して前後径が極めて長く, 先端に突起部を有する。釆状乳 頭は円錐形で，乳頭中程に舌根側から舌尖側へ傾斜した円形斜面があり，数個に分岐した乳頭の小突起が舌 根側から半円形にこの斜面を取り囲む。茸状乳頭は系状乳頭間に散在しており，系状乳頭より径が大きく， 丈の低い円丘状を呈する。強拡大で観察すると, 系状乳頭間, 系状乳頭下半部, 円形斜面に密集した微小堤 の存在を認めたが, 茸状乳頭と有郭乳頭の表面ではこの構造は明瞭ではなかった。

\section{文献}

1) Kessel, R. G. and Kardon, R. H. : Tissue and organ: A text-atlas of scanning electron microscope. p. 153-160, W. H. Freeman and Company, San Francisco, 1979.

2) Hume, W. J. and Potten, C. S. : The ordered columnar structure of mouse filiform pa- pillae. J. Cell Sci. 22 : 149-160, 1976.

3）藤田浄秀，大村 進，奥山富三，小田島哲世, 鈴木信治, 館山美樹, 松原敏夫 : 八ムスター舌 系状乳頭の形態と構造に関する研究; 第 1 編 舌前方 $2 / 3$ 部の系状乳頭について. 歯基礎誌 24 : 453-465, 1982.

4）小林 繁, 島村昭辰 : コウモリの舌乳頭の走查 電顕的研究. 1. ユビナガコウモリ，歯基礎誌 
23(Suppl) : 304, 1981.

5）小林 繁, 島村昭辰 : コウモリの舌乳頭の走査 電影的研究. 2. キクガシラコウモリ. 解剖誌 $57: 280,1982 \mathrm{a}$.

6）小林 繁, 島村昭辰 : コウモリの舌乳頭の走査 電影的研究. 4. コキクガシラコウモリ. 歯基 礎誌 24(Suppl), 304, 1982b.

7) Cleaton-Jones, P. and Fleisch, L. : A comparative study of the surface of keratinized and non-keratinized oral epithelia. J. Periodont. Res. 8 : 366-370, 1973.

8) McMillan, M. D. : A scanning electron microscopic study of keratinized epithelium of the hard palate of the rat. Arch. Oral Biol. 19 : 225-229, 1974.

9) Cleaton-Jones, P. : Surface characteristics of cells from different layers of keratinized and non-keratinized oral epithelia. J. Periodont. Res. 10 : 79-87, 1975.

10) Appleton, J. and Heaney, T. G.: A scanning electron microscope study of the surface features of porcine oral mucosa. J. Periodont. Res. 12 : 430-435, 1977.

11) McMillan, M. D. : The surface structure of the completely and incompletely orthokeratinized oral epithelium in the rat: a light, scanning and transmission electron microscope study. Am. J. Anat. 156 : 337-352, 1979.

12）斎藤 博, 高木知道, 野坂洋一郎: ミニブタの 口腔上皮細胞表面の微細構造; とくに微小堤に ついて. 歯基礎誌 $24: 406-417,1982$.

13）高木知道, 斉藤 博, 安蘇規子 : 微小堤の分化 機構 ; ヒトの舌の上皮細胞表面形態の走査型電 子顕微鏡による観察. 歯基礎誌 $18: 418-434$, 1976.

14）上原康生 : 結合組織除去法による非遊離細胞表 面の観察法. 電子顕徵鏡 16:40-46, 1981.

15) Karnovsky, M. J. : A formaldehyde-glutaral- dehyde fixative of high osmolality for use in electron microscopy. J. Cell Biol. 27(2, pt. 2) : 137A-138A, 1965.

16) Millonig, G.: Advantages of a phosphate buffer for $\mathrm{OsO}_{1}$ solutions in fixation. J. Appl. Physics 32 : 1637, 1961.

17) Farbman, A. I. : Morphological variability of keratohyalin. Anat. Res. 154 : 275-286, 1966.

18）雪野莞爾 : ラッテ舌粘膜上皮の微細構造と角化 について．札幌医誌 $31: 243-271 ， 1967$.

19）藤田浄秀, 賀来 享, 佐々木元賢 : 舌癌の実験 的形成に関する研究. 第 7 編 舌背部におけ る舌癌形成過程の組織学的研究. 口科誌 22 : 550-562, 1973.

20) Alvares, O. F. and Mayer, J. : Current concepts of the histology of oral mucosa [Variable features and regional differences in oral epithelium] p. 97-113, Charles C. Thomas. Publisher, U. S. A. 1971.

21) Mishima, Y., Matsunaka, M. and Nagao, S. : Subcellular changes in keratin and granular cells of keratin-stripped and psoriatic epidermis revealed by scanning and transmission electron microscopy. Qualitative and quantitative analysis. Acta Dermatovener (Stockholm) (Suppl.) $73: 83-100,1973$.

22) Centola, G. M. : Surface features of exfoliated vaginal epithelial cell during the oestrous cycle of the rat examined by scanning electron microscopy. J. Anat. $127: 553-561,1978$.

23) Fahrenbach, W. H. and Knutson, D. D. : Surface adaptations of the vertebrate epidermis to friction. J. Invest. Dermat. $65: 39-44$, 1975.

24) Sperry, D. G. and Wassersug, R. J. : A proposed function for microridges on epithelial cells. Anat. Rec. 185 : 253-258, 1976. 


\section{Explanation of figures}

Fig. 1 Dorsal surface of the tongue as revealed by scanning electron microscopy.

Fig. 2 Higher magnification of the lingual apex of Fig. 1. The most anterior is narrowly protruded.

Fig. 3 The filiform and fungiform papillae on the dorsal surface.

Fig. 4 The filiform papilla in the relatively anterior part of the lingual dorsal surface.

Fig. 5 The filiform papilla in the relatively posterior part of the lingual dorsal surface.

Fig. 6 The fungiform papilla.

Fig. 7 The circumvallata papilla.

Fig. 8 The lingual dorsal surface between the filiform papillae. Extracellular substance coated thickly over the real epithelial cell surface. Microridges of the epithelial cell surface (EP) are seen from a crack of piled substance.

Fig. 9 The dorsal epithelial surface between the filiform papillae. Extracellular substance was removed by the hydrolysis method with $8 \mathrm{~N} \mathrm{HCl}$. Microridges of the epithelial cell surface are clearly observed.

Fig. 10 The epithelial surface in the basal area of filiform papilla. Extracellular substance was removed by the same method as in Fig. 9. Epithelial cell microridges are also seen.

Fig. 11 The epithelial cell surface in the upper branched area of filiform papilla. Extracellular substance was hydrolysed with $8 \mathrm{~N} \mathrm{HCl}$. Microridges on the epithelial cell surface are not clear. Note the presence of fine pores all over the epithelial cell surface. Arrow indicates the marginal region of cells.

Fig. 12 The epithelial cell surface of the fungiform papilla. Extracellular substance was also hydrolysed. Microridges are obscure. Instead, fine pores are scattered in the cell surface.

Fig. 13 The epithelial cell surface of the lingual root. Without acid hydrolysis, microridges of the epithelial cell surface are obviously recognized in this area.

Fig. 14 Cut surface of the lingual dorsal epithelium showing the distribution of microridges.

Fig. 15 Higher magnification of Fig. 14. A: Microridges on the free cell surface showing a network-like structure. B: Microridges on the lower layered cell surface showing a parallel pattern. 

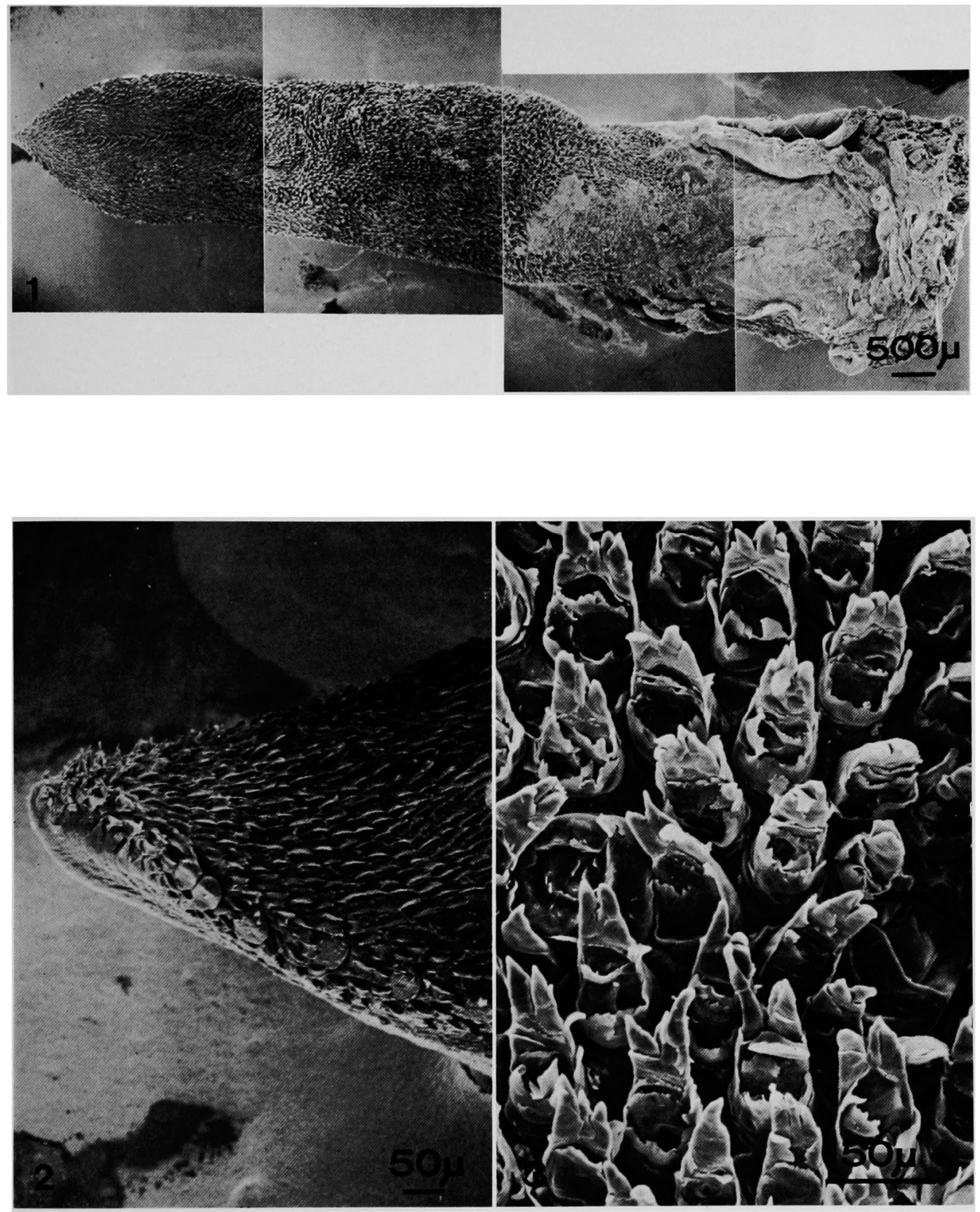


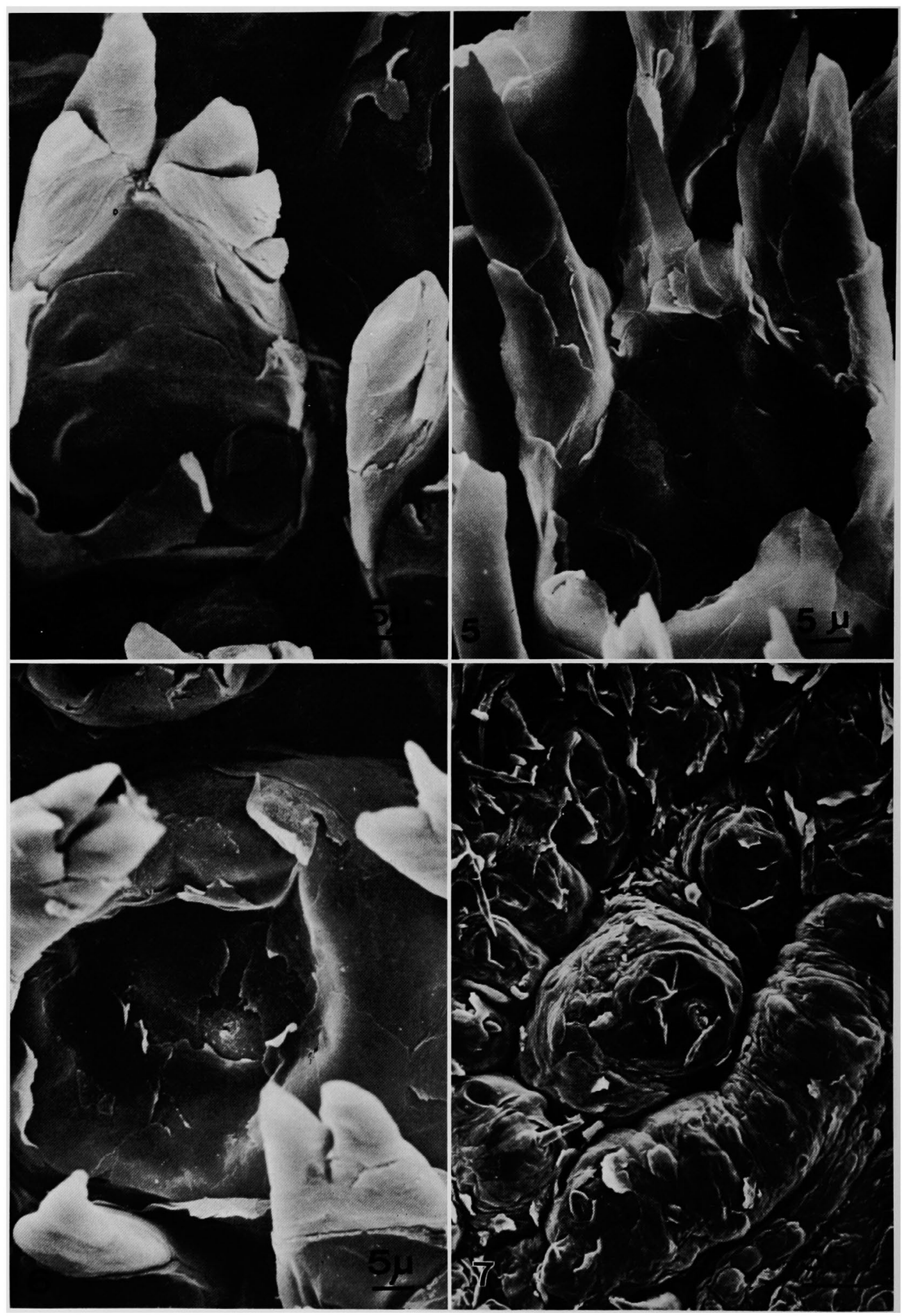




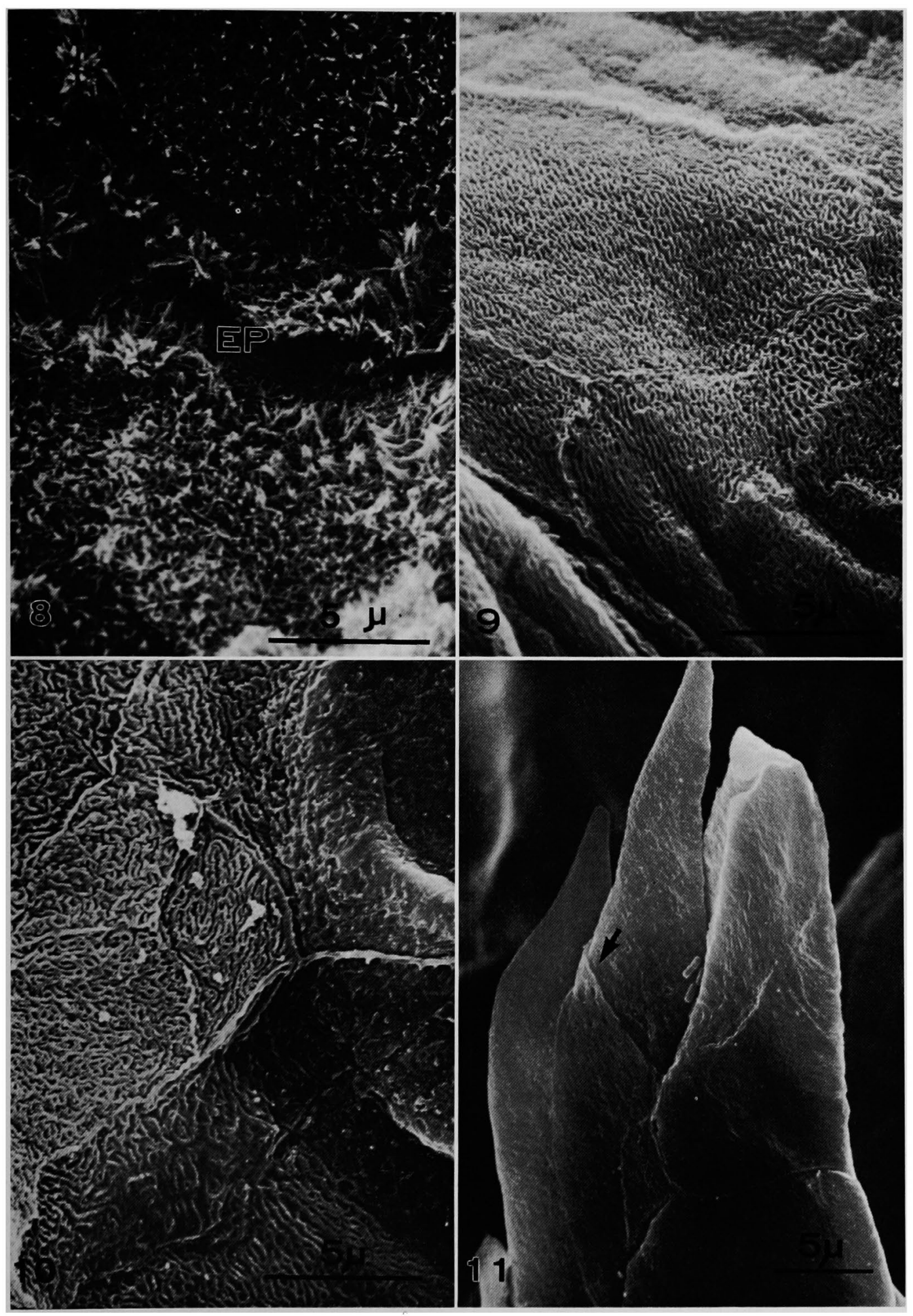




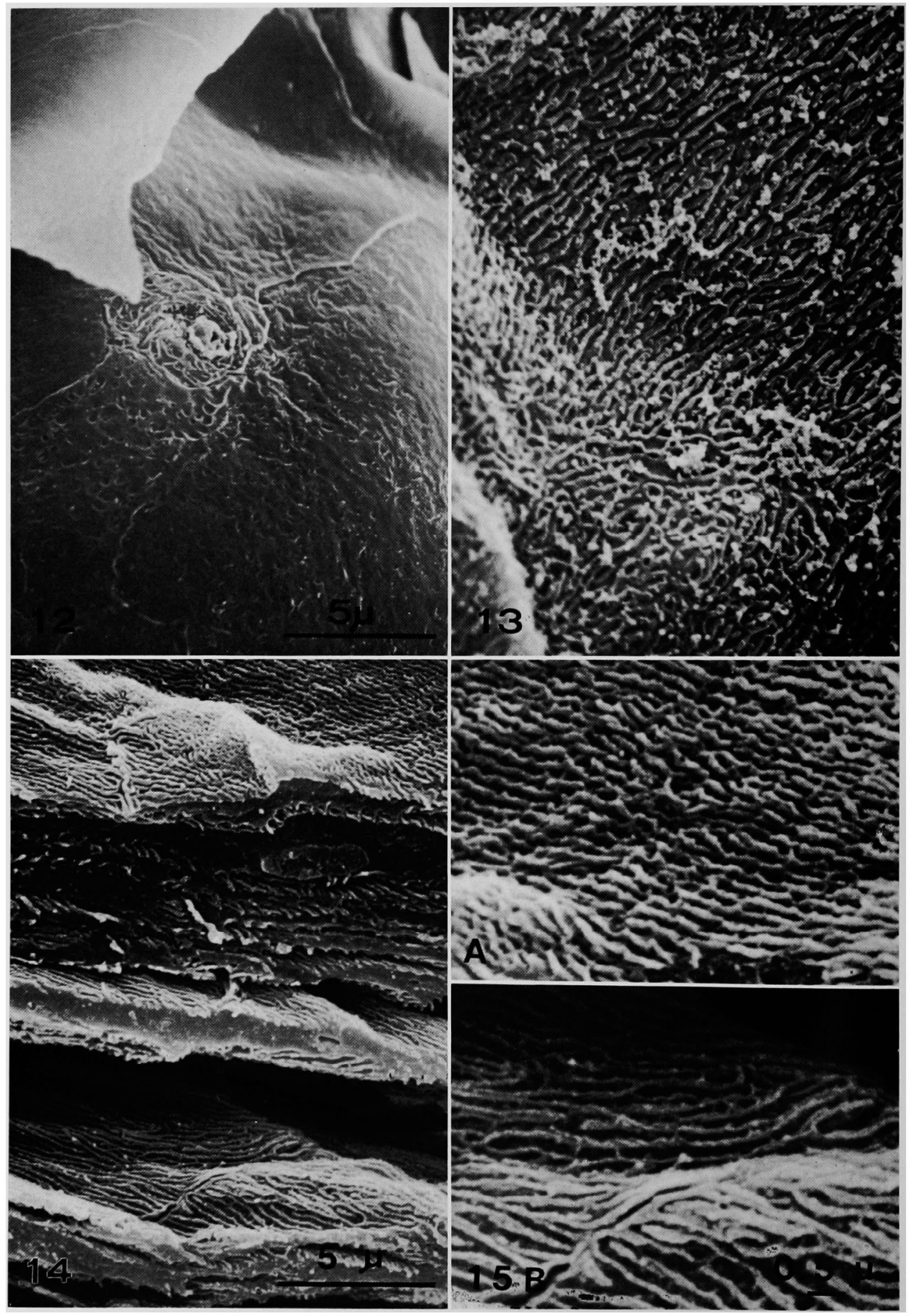

